\title{
Diallyl Disulphide Protects against Colon Cancer in vitro, of HT-29 Cells and in Male Rabbits of Colon Cancer Model: An Analysis of Genetic and Epigenetic Variations
}

\author{
Mohammed O Altonsy ${ }^{1}$, Tito N Habib ${ }^{1 *}$, El-Sabry A Hassanain², and Gehad S Mokhtar ${ }^{3}$ \\ ${ }^{1}$ Molecular Genetics Lab, Zoology Department, Faculty of Science, Sohag University, Egypt \\ ${ }^{2}$ Animal Physiology Lab, Zoology Department, Faculty of Science, Sohag University, Egypt \\ ${ }^{3}$ Central Lab, Faculty of medicine, Sohag University, Egypt
}

\begin{abstract}
Diet and dietary habits are currently accused of being among cancer causing agents. The present study was carried out in a trial to point at the beneficial anti-cancer properties of one the most Egyptian traditional food components (Garlic). We studied the anti-cancerous properties of Diallyl disulphide (DADS), a major organosulfur compound in garlic oil, on HT29 colon cancer cell line and in vivo of male rabbits (Oryctolagus cuniculus) as an animal model of colon cancer. DADS showed differential effect on the expression of a group of genes, as it down-regulated the expression of oncogenes (e.g., CTNNB1, CCDN1, BIRC5, MYC and AKT), while up-regulated the expression of tumour suppressor gene (TP53) and apoptosis regulator gene (BAX). DADS' apoptotic effect was also seen via inducing the expression of cytochrome $c$ and activation of caspase-3. Moreover, DADS induced chromatin configuration changes through increasing histone acetylation of histone-3 and -4 . Examination of 1,2 dimethyl hydrazine (DMH) induced cancer in vivo model (O. cuniculus) showed histological changes characteristic for colon tumorigenesis such as, hyperplastic intraepithelial lesions, neoplastic changes and lymphocytes infiltration, which were strongly attenuated in animals coinjected with both DADS and DMH and were not observed in the animals that received DADS prior to DMH treatment. This study suggested the protective properties of DADS against colon cancer in vitro and in vivo.
\end{abstract}

Keywords: Colon cancer; Diallyl disulphide; Dimethyl hydrazine; Histone acetylation; Apoptosis

Abbreviations: DADS: Diallyl Disulphide; FBS: Foetal Bovine Serum; PBS: Phosphate Buffered Saline; RIPA: Radio-Immuno Precipitation Assay; RT: Room Temperature

\section{Introduction}

In Egypt, the recent number of cancer patients per year was estimated to be 70,000. The highest percentage of these cases were recorded in Upper Egypt [1]; a matter needs to be urgently and seriously investigated. The causes of these elevated numbers of daily discovered cases cannot be simply grouped under the title of heredity factors, because cancer is a multi-factorial disease [2], and there are globally growing scientific evidences suggest that it could be controlled through modifying the life style of the susceptible individuals $[3,4]$. Among those factors that were strongly accused by their involvement in inducing cancer are pollution, in air, water and soil. The repetitive exposure to high concentrations of such pollutants was correlated with cancer incidence [5-7], particularly colorectal cancers [8].

Because dietary habits have pronounced impacts on human health/ disease status, the correlation between cancer incidence and diet concerned the researchers for the last few decades, to the extent that Doll and Peto (1981) made to state that $35 \%$ of cancer deaths may be related to dietary factors [9]; Abdulla and Gruber, (2000), Sabate and Ang, (2009), who reported that $\sim 40 \%$ of cancers are directly linked to the diet $[10,11]$. Adversely, balanced and healthy foods, showed protective activities displayed by certain dietary components against cancer. These beneficial components have attracted the scientist's attention (e.g., Apple polyphenol extract), which prevents intestinal polyps formation in rats [12], fish oil, reduces DNA adduct formation in the rat colon [13], germinated barley, treats colitis and reduces the risk of colitic cancer [14]. Recently, one of the traditional ingredients in the Egyptian meals (Garlic), particularly DADS [15] showed strong anticancerous properties manifested the induction of cell cycle arrest and microtubules formation disruption in human breast adenocarcinoma cells (MDA-MB-435) [16], induced apoptosis in human leukaemia cells (HL-60) [17] and ceased human neuroblastoma cellular proliferation [18]. DADS also showed anti-invasive activities in human prostate carcinoma cells (LNCaP) through tightening the tight junctions and inhibition of matrix metalloproteinase activities [19]. These studies clearly suggested that diet is closely related with both causation and prevention of cancer.

In this work, we studied the differential impact of DADS on the expression of a group of genes known to be involved in regulation of colon tumorigenesis in vitro, in the human colon cancer cell-model (HT-29). Then we investigated both prophylactic and heeling impacts of DADS in DMH colon cancer animal model [20], using laboratory male rabbit (O. cuniculus). Our results demonstrated that DADS differentially repressed oncogenes but induced the expression of tumor suppressor genes in vitro and increased the resistance of $O$. cuniculus to develop colon cancer after receiving multiple doses of DMH.

\section{Materials and Methods}

\section{Cell culture and treatments}

HT-29 cells (American Type Culture Collection), were propagated in Dulbecco's modified Eagle's minimum essential medium (DMEM, Life technologies, catalogue number: 11320-033) supplemented with

*Corresponding author: Tito Naeem Habib, Molecular Genetics Lab, Zoology Department, Faculty of Science, Sohag University, Egypt, Tel: +201013793306 (Mob); Fax: +20934601159; E-mail: titohabib99@yahoo.com

Received September 10, 2015; Accepted September 21, 2015; Published September 28, 2015

Citation: Altonsy MO, Habib TN, Hassanain EISA, Mokhtar GS (2015) Dially Disulphide Protects against Colon Cancer in vitro, of HT-29 Cells and in Male Rabbits of Colon Cancer Model: An Analysis of Genetic and Epigenetic Variations. Mol Biol 4: 136. doi:10.4172/2168-9547.1000136

Copyright: @ 2015 Altonsy MO, et al. This is an open-access article distributed under the terms of the Creative Commons Attribution License, which permits unrestricted use, distribution, and reproduction in any medium, provided the original author and source are credited. 
$10 \%$ heat-inactivated $\left(60^{\circ} \mathrm{C}, 30 \mathrm{~min}\right)$ fetal bovine serum (FBS; Gibco ${ }^{\circ}$, catalogue number: 12484-010) and antibiotics (100 U/ml penicillin, $100 \mu \mathrm{g} / \mathrm{ml}$ streptomycin, Sigma, catalogue number: P4333). Cells were incubated at $37^{\circ} \mathrm{C}$ in a $5 \% \mathrm{CO}_{2}$ atmosphere. For the experiment the cells were sub cultured in 6-well plates at a density of $10^{5}$ cells/well for $48 \mathrm{~h}$ and serum starved overnight before treatment. Cells were treated with vehicle control (DMSO, Sigma, catalogue number: W387509), or DADS (Sigma-Aldrich, Catalogue number 317691) supplemented in the culturing medium to a final concentration of $100 \mu \mathrm{M}$ for $8 \mathrm{~h}$.

\section{Real-time reverse transcription quantitative PCR (RT-qPCR)}

RNA was prepared using TRIzol reagent and the Pure Link RNA mini kit (Life Technologies, catalogue number: 12183018) following the kit's instruction. RNA was reverse-transcribed and GPCR was performed by PCR as the following: Total RNA $(1 \mu \mathrm{g})$ was reverse transcribed using the high-capacity cDNA reverse transcription kit (Life Technologies, Catalog number: 4368813) according to the manufacture instructions. cDNA samples were diluted 1:5. RT-PCR reaction mixture was prepared by adding $4 \mu \mathrm{L}$ cDNA, $10 \mu \mathrm{L}$ Fast SYBR Green PCR Master Mix (Life Technologies, catalogue number: 4385612), $0.6 \mu$ of each primer of 10 $\mu \mathrm{M}$ working concentration and $4.8 \mu \mathrm{L} \mathrm{H}_{2} \mathrm{O}$. Amplification conditions were initial one cycle for denaturation and enzyme activation at $95^{\circ} \mathrm{C}$ for $20 \mathrm{sec}$., followed by 40 cycles of $95^{\circ} \mathrm{C}$ for $3 \mathrm{sec}, 60^{\circ} \mathrm{C}, 30 \mathrm{sec}$. The obtained $\mathrm{C}_{\mathrm{T}}$ values were normalized to the RPL19 (60S ribosomal protein L19). Expression levels for different conditions were obtained by comparing the mean $\mathrm{C}_{\mathrm{T}}$ value for each gene relative to the mean $\mathrm{RPL} 19 \mathrm{C}_{\mathrm{T}}$ value. For repressed genes (i.e., a $\Delta \Delta \mathrm{Ct}$ value $<0.0$ ), relative fold change is depicted graphically as - $\left(2^{\mathrm{x}}\right)$, where $\mathrm{x}$ is the absolute value of the $\Delta \Delta$ Ct value.

Data were generally analyzed in biologic triplicate and technical duplicate and are expressed as mean \pm SE. We used the two-tailed (or paired) Student's t-test, using Microsoft Excel, to determine the significant differences with probability values. $(\leq 0.05$ were considered significant). Primers with specific sequence used in the experiment were purchased from Macrogen, Seoul, Korea.

CTNNB1 primer pairs:

\section{[F] 5'-CCTCAGATGGTGTCTGCTATTG-3',}

[R] 5'-CCTTCCATCCCTTCCTGTTTAG-3'.

CYCLIN-D1 primer pairs:

[F] 5'-CACACACACACACACAAACC-3',

[R] 5'-CCTCCCTTCAACACTTCCTAAA-3'.

SURVIVIN primer pairs:

[F] 5'-GCACCACTTCCAGGGTTTAT-3',

[R] 5'-CAGACGCTTCCTATCACTCTATTC-3'.

CMYC primer pairs:

[F] 5'-GCTGTAGTAATTCCAGCGAGAG-3',

[R] 5'-GAGTCGTAGTCGAGGTCATAGT-3'.

$A K T$ primer pairs:

[F] 5'-CGCTACTTCCTCCTCAAGAATG-3',

[R] 5'-GCCCGAAGTCTGTGATCTTAAT-3.

USP28 primer pairs:

[F] 5'-CACTGACATCTTCTCGGTCTTC-3',

\section{[R] 5'-CTCTТCTTCССАСТССТСТАСТ-3'.}

P53 primer pairs:

[F] 5'-AGTCTACCTCCCGCCATAAA-3',

[R] 5'-CCCAAACATCCCTCACAGTAAA-3'.

$B A K$ primer pairs:

[F] 5'-CTCTCССТTCСТСТСТССТTATAG-3',

[R] 5'-GGGATTCCTAGTGGTGTTGATAG-3'.

$B A X$ primer pairs:

[F] 5'-CAGACCGTGACCATCTTTGT-3',

[R] 5'-GTGTCCCGAAGGAGGTTTATT-3'.

\section{Western blot}

Following treatment, DADS or vehicle control, cellular lysates were prepared from HT-29 cells by washing the plates with ice cold phosphate buffer saline (PBS) followed by scraping the cells with plastic scraper and collecting the cells suspension in pre-chilled Falcon tubes. Cells were pelleted by centrifugation $(250 x g)$ for $5 \mathrm{~min}$ and the pellets were resuspended in radio immunoprecipitation assay buffer (RIPA) [ $150 \mathrm{mM}$ sodium chloride, $1.0 \% \mathrm{NP}-40$ or Triton X-100, $0.5 \%$ sodium deoxycholate, $0.1 \%$ SDS (sodium dodecyl sulphate), $50 \mathrm{mM}$ Tris, $\mathrm{pH}$ 8.0] containing Halt ${ }^{\mathrm{Tw}}$ Protease Inhibitor Cocktail, Life Technologies, catalog number: 78437 (1 X, final concentration). Total protein concentration were determined via protein assay kit (BioRad, Cat. No. 500-0006) and $50 \mu \mathrm{g}$ protein were separated by SDS polyacrylamide gel electrophoreses (PAGE).

Protein bands were transferred to Polyvinylidene fluoride membrane (PVDF, Amersham, Cat. No. 10600023), then, the membrane were blocked overnight in the blocking buffer $(20 \mathrm{mM}$ Tris $\mathrm{HCl}, 500$ $\mathrm{mM} \mathrm{NaCl}, \mathrm{pH} 7.5$ ) containing $5 \%$ non-fat dry milk (BioRad, Cat. No. 170-6404XTU). Desired protein bands were detected by incubating the membranes for $2 \mathrm{~h}$ at room temperature in the blocking buffer containing 3\% non-fat dry milk and first antibody in a manufacturing recommended dilutions. We used antibodies to detect beta catenin, cyclin D1, surviving, c-myc, AKT, pAKT, P53, Bak, Bax, Ace-H3 [acetyl K27], Ace-H4 [acetyl K91], cytochrome $c$, caspase-3 [full length protein], and $\beta$-actin; corresponding catalogue numbers respectively are ab6302, ab16663, ab182132, ab32072, ab32505, ab66138, ab179477, ab32371, ab7977, ab4729, ab4627, ab133504, ab13847 and ab6276, all were purchased from ABCAM; USP28 antibody was purchased from Cell signaling (Cat. No. 4217). Immuno-detected band visualization was carried out using ECL plus Western Blotting Substrate (Thermo, Cat. No. PI32106).

\section{Animal model}

The experimental animal we used was $O$. cuniculus, four weeks old, obtained from the animal house of Sohag University, and were housed in polypropylene cages and maintained at controlled conditions of temperature $\approx 28^{\circ} \mathrm{C}$ with a $12 \mathrm{~h}$ light and $12 \mathrm{~h}$ dark cycles and fed commercial pellet diet. Animals were divided into five groups, four animals each, and treated for four weeks as the following: group (A) received vehicle control only (distilled water containing $1 \mathrm{mM}$ EDTA) via subcutaneous injection, group (B) received DMH only [20 mg/kg dissolved in the vehicle control], group (C) received DADS only (60 mg/ $\mathrm{kg}$, via intragastric intubation), group (D) received DADS and DMH, and finally group (E) received DADS for the first 4 weeks followed by $\mathrm{DMH}$ for extra 4 weeks. All treatments were received three times a 
week for the entire experiment time. All experimental procedures were conducted according to the ethical standards of Sohag University for animal experimentation.

\section{Histopathology}

At the end of the experiment, animals were anesthetized using ether inhalation, sacrificed, carefully dissected, and the colon region from each animal were fixed in $10 \%$ formalin and imbedded in paraffin wax to prepare paraffin blocks. Paraffin sections ( $7 \mu \mathrm{m}$ thickness) were then deparaffinized in xylene and hydrated in descending series of ethyl alcohol and stained with Hematoxylin and Eosin (H and E). Stainedsamples Slides were mounted in DPX medium and observed under light microscope (Axio Lab. A1, Carl ZEISS, Germany) equipped with AxioCamERc5s camera.

\section{Results}

\section{DADS differentially regulated gene expression in HT-29 cells}

DADS was reported to having anti-cancer properties and in a step to understand its' mechanism action, we proposed that it might modulate the expression of the gene machinery that controls carcinogenesis in the colonic cells. Therefore, we established a cell culture system using HT-29 cells (colon cancer cell model) and measured the mRNA levels by Real-Time PCR of a group of genes that are implicated in colorectal carcinogenesis (CTNNB1, CCND1, BIRC5, MYC, AKT and USP28), and in the same time we determined the mRNA levels of the tumor suppressor TP53 gene, as well as BAK1 and BAX genes, which are involved in controlling the apoptotic pathway.

Normalized $\mathrm{C}_{\mathrm{T}}$ values to the RPL19 (ribosomal protein L19) demonstrated that DADS significantly down regulated the expression of CTNNB1, CCND1, BIRC5, MYC, AKT but did not affect the mRNA level of USP28 gene. While mRNA levels of TP53 were significantly increased post DADS treatment compared to its levels in the cells treated with vehicle control. DADS also significantly increased the mRNA levels of $B A X$ but did not affect the BAK1 mRNA (Figure 1 and Table 1).

Gene expression process passes through multiple molecular steps within the cell, starts with mRNA transcription followed by post transcription modifications and functional protein synthesis. The impact of DADS on mRNA, we seen above, may or may not extend to the following steps and affect the protein levels. Thus, we measured the

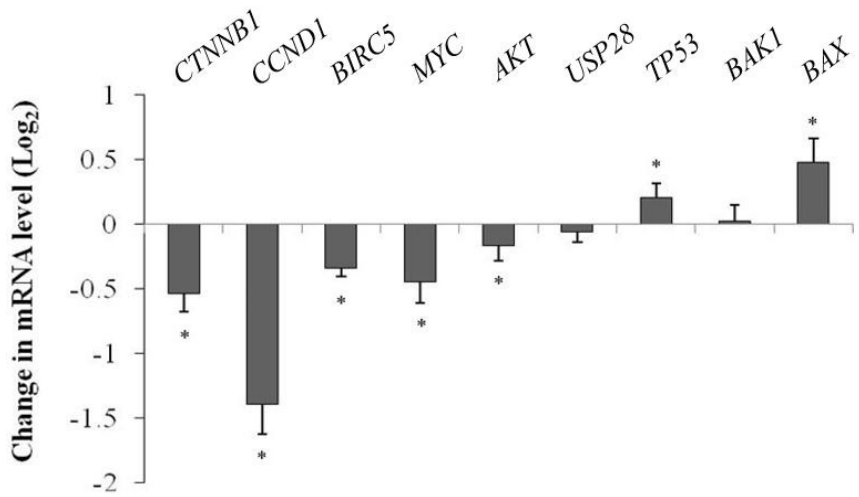

Figure 1: Differential impact of DADS on gene expression in H292 cells. $80 \%$ confluent cells were treated with vehicle control (DMSO) or DADS for $8 \mathrm{~h}$. Bars graphs indicate mean CT values of four independent biological replicates normalized to RPL19 CT values and relative to vehicle control \pm S.D. $*$ Significant $(\mathrm{P} \leq 0.05)$.

\begin{tabular}{|c|c|c|c|}
\hline Gene name & \% Fold change & S.D. & $\boldsymbol{P}$ value $\leq$ \\
\hline CTNNB1 & -31.22 & \pm 0.1373 & $0.004221^{*}$ \\
\hline CCDN1 & -62.02 & \pm 0.2311 & $0.006642^{*}$ \\
\hline BIRC5 & -20.83 & \pm 0.0702 & $0.004805^{*}$ \\
\hline MYC & -26.64 & \pm 0.1661 & $0.002574^{*}$ \\
\hline$A K T$ & -10.68 & \pm 0.1235 & $0.004991^{*}$ \\
\hline USP28 & -3.87 & \pm 0.0852 & 0.08038 \\
\hline TP53 & 15.02 & \pm 0.1092 & $0.00297^{*}$ \\
\hline BAK1 & 01.70 & \pm 0.1245 & 0.063341 \\
\hline BAX & 39.12 & \pm 0.1846 & $0.002741^{*}$ \\
\hline
\end{tabular}

Table 1: RT-PCR data analysis of DADS impact on the gene expression in HT-29 cells, CT values were normalized to those of RPL19 and relative to vehicle control. Data are mean of four independent experiments $(n=4), S D=$ standard deviation, * $p$ $\leq 0.05$ considered significant.

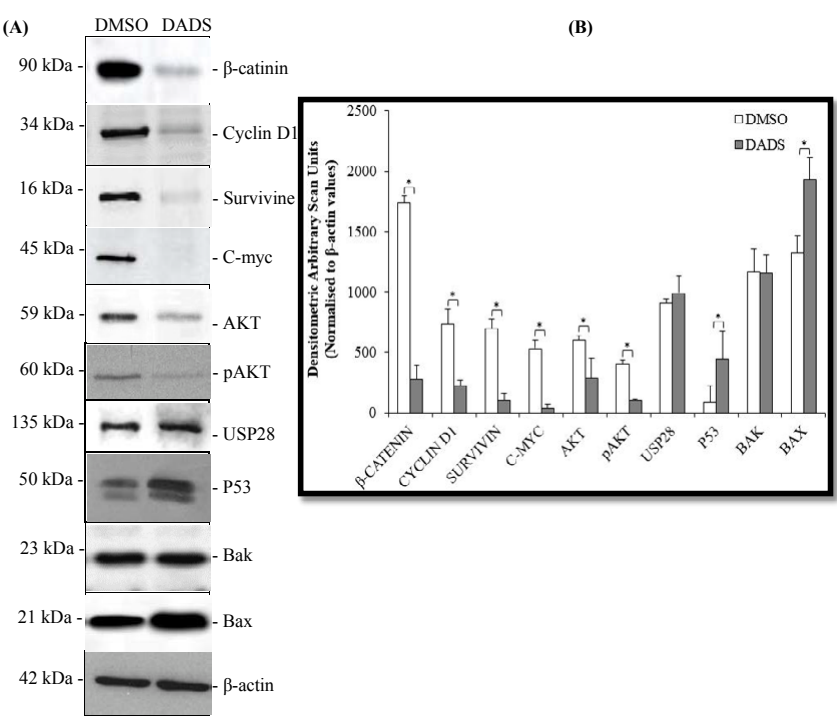

Figure 2: DADS differential modulation of the protein levels in HT-29 cells. (A) Cellular lysates of vehicle control and DADS treated cells $(100 \mu \mathrm{M}, 8 \mathrm{~h})$ were denatured and $50 \mu \mathrm{g} /$ well were separated by SDS-PAGE and trans-blotted into PVDF membrane and immunoprobed following the standard Western blot protocol. (B) Bands intensity was determined using TotalLabTM gel analysis software and expressed as arbitrary scan units after normalization to $\beta$-actin values. The reported results are mean \pm SE of three independent experiments; ${ }^{*} p \leq 0.05$.

levels of functional proteins of the above mentioned genes before and after DADS treatment using Western Blot (W.B.) analysis.

The protein data showed similar pattern to the mRNA levels indicative of the extended impact of DADS in differentially modulating not only mRNA message, but also the levels of the functional proteins; as compared to levels of the same proteins in the cells treated only with the vehicle control. DADS decreased the protein levels of CTNNB1, CYCLIN D1, SURVIVIN, C-MYC and AKT. HT-29 cells showed lower level of AKT activation (phosphorylated pAKT), suggesting that DADS treatment decreased the pro-survival signaling within the colon cancer cell. On the other hand HT-29 cells showed an increase in P53 and BAX proteins, while spared the USP28 and BAK protein levels (Figure 2).

We also studied the changes in the levels of acetylated histone-3 (Ace-H3, acetyl K27) and -4 (Ace-H4, acetyl K91) in the cellular lysates of HT-29 cells that were treated with DADS or vehicle control. As expected, DADS significantly increased the levels of acetylated forms of both $\mathrm{H} 3$ and H4 (Figure 3). This might explain the alteration in gene expression and protein levels, which was observed by RT-PCR 
Citation: Altonsy MO, Habib TN, Hassanain EISA, Mokhtar GS (2015) Diallyl Disulphide Protects against Colon Cancer in vitro, of HT-29 Cells and in Male Rabbits of Colon Cancer Model: An Analysis of Genetic and Epigenetic Variations. Mol Biol 4: 136. doi:10.4172/2168-9547.1000136

Page 4 of 7

and W.B., respectively, after DADS treatment. In addition to this, we measured the cytochrome $c$ and caspase-3 (pro- and active forms) by W.B. analysis in the cellular lysates of HT-29 cells treated with either DADS or vehicle control (Figure 3).

(A)

DMSO DADS
(B)

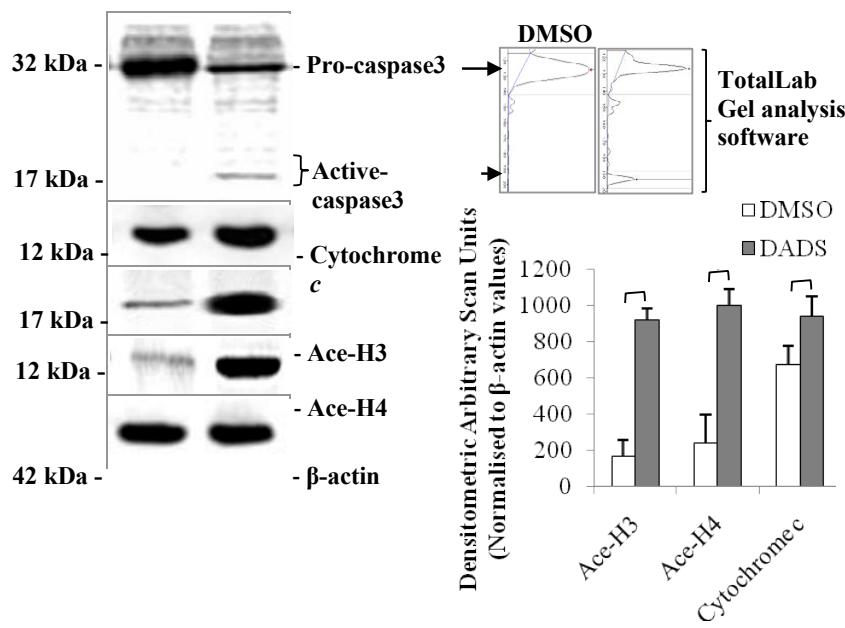

Figure 3: DADS induction of the apoptosis machinery proteins (Caspase-3 and cytochrome $c$ ) and changes chromatin confirmation in HT-29 cells. (A) Western blot showed that DADS induced caspase-3 activation ( $17 \mathrm{kDa}$ band), caused an increasing of cytochrome $c$ expression and induced the acetylation of histone- 3 and -4 . Gel analysis software $(B$, upper graph) detected an active caspase- 3 band in DADS treated cells, but not detected in control, while it accompanied with a reduction of the level of pro-caspase-3 band. Densitometric analysis (B, lower graph) depicted the significant increase $(p \leq 0.05)$ of cytochrome $c$, Ace-H3 and $-\mathrm{H} 4$ post DADS treatment compared to control. The results are mean \pm SE of three independent experiments.
An increase in the level of cytochrome $c$ and decrease in the level of pro-caspase- 3 were observed accompanied with the appearance of active caspase- 3 protein bands $(12-21 \mathrm{kDa})$ in the cellular lysates of DADS treated cells (Figure 3).

For further investigation we generated an in vivo model for colorectal cancer by injecting the laboratory male rabbit (O. cuniculus) with $\mathrm{DMH}$ as mentioned in the materials and method section. Animals were divided into five groups: group (A) received vehicle control only, group (B) received DMH only, group $(\mathrm{C})$ received DADS only, group (D) received DADS and DMH and group (E) received DADS first for 4 weeks followed by DMH treatment. Microscopic examination of colonic tissues of O. cuniculus showed normal organization of histological layers with flat mucosa and numerous straight tubular crypts that extend down to the muscularis mucosa (Figure $4 \mathrm{~A}, 4 \mathrm{~F}$ and $4 \mathrm{~K}$ ).

While the colonic sections prepared from animals treated with $\mathrm{DMH}$ (Figure 4B, 4G and 4L) displayed histological and cytological changes characteristic for hyperplastic intraepithelial lesions, such as crowded nuclei without stratification (L, the red arrow), elongation of the crypts (G, red arrows). Moreover, DMH displayed cytological features characteristic for neoplasia, such as hypercellularity accompanied with hyperchromatic nuclei and high nuclear/cytoplasmic ratio (Figure $4 \mathrm{~L}$, red arrow). DMH also caused lymphocytes infiltration (Figure 4B and $4 \mathrm{G}$, black arrows). Such kind of histological and cytological apparitions were not seen in the DADS group (Figure $4 \mathrm{C}$, $4 \mathrm{H}$ and $4 \mathrm{M}$ ) which looked similar to the control group, and were strongly attenuated in the DMH+DADS group (Figure 4D, 4I and 4N), and strongly enhanced the resistance against DMH carcinogenicity in the group that received $\mathrm{DMH}$ after 4 weeks of DADS treatment, as most of the above described histological apparitions were not seen (Figure 4E, 4J and 4O).

\section{Discussion}

In the present study, we aimed to determine the positive role of DADS in protecting against colon cancer; particularly with the current
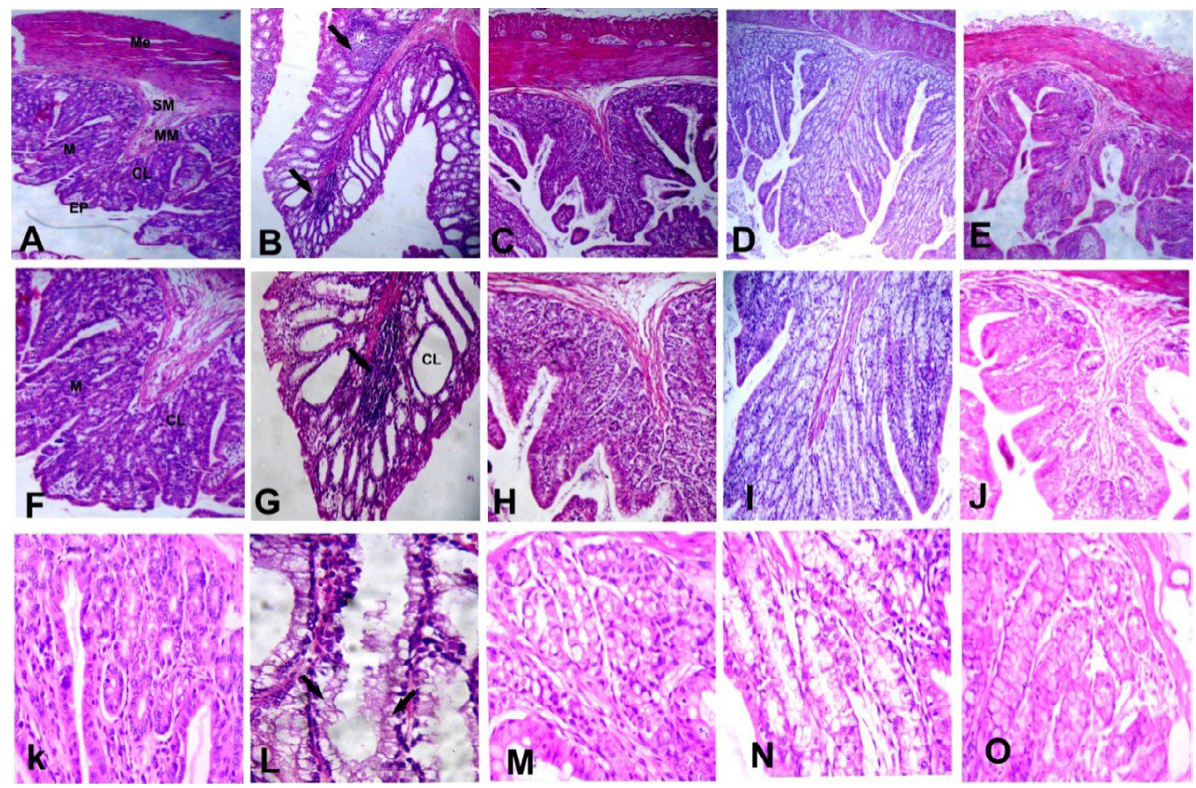

Figure 4: Photomicrograph of $O$. cuniculus colonic tissues: Control group ( $\mathrm{A}, \mathrm{F}$ and $\mathrm{K}$ ) showed a normal organization of the histological layers with a flat mucosa and numerous straight tubular crypts that were extended down to the muscularis mucosa. DMH treated group $(B, G, L)$ displayed changes that were characteristic for hyperplastic intraepithelial lesions in such kind of histological and cytological apparitions that were not observed in DADS group (C, $\mathrm{H}$ and $\mathrm{M}$ ), and in DMH post DADS group (E, J and O), while it were strongly attenuated in DMH+DADS group (D, I and N). Muscularis [Me], Submucosa [SM], Muscularis mucosa [MM], Crypts of Lieberkühn [CL], Mucosa [M] and Simple Columnar Epithelial cells [EP] 
accusation to diet and dietary habits of being among cancer causing agents [21-23] and in a country like Egypt facing serious problem of yearly elevated numbers of cancer patients. The rationale behind choosing DADS for studying its anti-cancerous activities against colon cancer was: 1- DADS is a major organosulfur compound in garlic oil [15], and 2- Garlic is one of the most consumable Egyptian traditional foods.

The cell line we used, HT-29, which was isolated from a human primary colonic adenocarcinoma tissue in 1964 by Fogh [24]. This cell line is being extensively used as an in vitro model to test the sensitivity of colon cancers towards chemotherapeutic drugs [25]. In a previous study, we showed that after $24 \mathrm{hr}$ DADS reduced viability and proliferation of colonic adenocarcinoma cells (HT-29) in a dosed dependent way. In the present work, the cultured HT-29 cells were treated with DADS and monitored the expression of the genes that are known to be involved in the carcinogenesis process in the colon, at both levels mRNA and protein.

The results demonstrated that DADS differentially modulated the expression of such genes through enhancing the expression of tumour suppressor genes and concomitantly repressing the expression of oncogenes. RT-PCR and W.B. data showed that the mRNA and protein levels of CTNNB1 ( $\beta$-catenin), CCND1 (cyclin d1), BIRC5 (survivin), MYC (c-myc) and $A K T$ were significantly repressed after DADS treatments compared to their levels in the cells treated only with the vehicle control. These genes are known to control the carcinogenesis process as $\beta$-catenin is important in forming the adherens junction in epithelial cells, it also controls cell growth and differentiation during both normal development and tumorigenesis [26-28]. Cyclin d1 function is to regulate CDK kinases (Cyclindependent kinases), which are involved in regulating transcription, mRNA processing and cell cycle control. Over-expression of this gene, as seen in a variety of tumors, alters cell cycle progression and may contribute to tumorigenesis $[29,30]$. Survivin inhibits the progression of programmed cell death (apoptosis) by inhibiting caspase family of protease enzymes and thereby promotes cellular sustainability and tumour growth [31]. C-myc itself is a transcription factor and if it is over expressed it alters the expression of many other genes involved in cell proliferation resulting in cancer progression [32]. AKT is involved in protein synthesis pathways, and if its level is up normally elevated within the cell, it leads to cellular hypertrophy $[33,34]$. It also works as survival factor, upon activation (phosphorylation) through inhibiting apoptosis [35]. On the other hand, DADS up regulated the expression of P53 and BAX mRNA and protein. P53 is an important cell cycle regulator protein, it activates apoptosis in case of irreversible DNA damage [36]. P53 deficiency mediates tumour formation in mammary glands [37] and elicit chemotherapeutic resistance in colon cancer cells via inducing the survival pathway [38]. BAX is a member of BCL-2 family, which regulates apoptosis via controlling mitochondrial cytochrome $c$ release and caspases family activation [39].

DADS' induction of the expression of such genes is indicative of its protective properties against cancer. Observed apoptotic impact of DADS comes consistent with the results obtained from the study performed on other cancer cells, such as human leukaemia HL-60 cells and MDA-MB- 435 breast cancer cells, where DADS arrested the mitotic division and activated apoptosis [16,40]. In addition, chaperone protein family, Hsp70 and Hsp90 are over-expressed in a wide range of tumor types (both solid tumors and hematological malignancies), and play essential roles in apoptosis, cell proliferation, metastases, angiogenesis, and invasion pathways in cancer cell metabolism. They provide stabilization; regulation and maintenance of oncogenic client proteins (Her-2, Cdk-4, Akt, Raf-1), thus promote cancer cell survival [41]. Some approaches being used or proposed in cancer therapy based on the in inhibition of Hsp90, Hsp70 and Hsp27 [42].

In a previous study, we proved that the apoptotic effect of DADS in breast cancer cells MCF-7 might be due to the upstream alterations that happened in the chromatin conformation post DADS treatment, which might lead to changes in gene expression [43]. Therefore, DADS ability was tested to activate $\mathrm{H} 3$ and $\mathrm{H} 4$ acetylation and thereby initiation of apoptosis by measuring the levels of acetylated forms of $\mathrm{H} 3$ (Ace-H3, acetyl K27) and H4 (Ace-H4, acetyl K91) beside two of the well-known apoptotic molecular markers, cytochrome $c$ and active caspase-3 [44,45]. A significant increase was observed in the acetylated form of histone-3 (Ace-H3) and -4 (Ace-H4) and in the level of cytochrome $c$, along with the appearance of active caspase- 3 protein bands, compared to vehicle treated cells.

Induction of histone acetylation was correlated in many studies with the initiation of the programmed cell death or apoptosis, particularly in cancer cells $[46,47]$. These data clearly suggest that DADS provoked apoptosis in HT-29 cells and this may be caused by the chromatin changes (H3 and $\mathrm{H} 4$ acetylation) that altered gene expression and caused an elevation in the levels of apoptotic genes machinery (BAX, cytochrome $c$ ) and ultimately led to caspase-3 activation in HT29 cells. Then, one question could be asked? Does DADS exert a similar effect in $v i v o$ ? To answer this question we designed an animal model for colon cancer (DMH induced colorectal cancer in laboratory male rabbit) [20].

Histological and cytological changes characteristic for colon tumorigenesis was seen in the histological sections prepared from O. cuniculus colonic region post DMH treatments. Such changes were hyperplastic intraepithelial lesions, indicated by crowded nuclei without stratification, disappearance of the mitotic figures on the surface of crypts and elongation of the crypts. In addition to neoplastic changes (e.g., hypercellularity, hyperchromatic nuclei and high nuclear/ cytoplasmic ratio), lymphocytes infiltration was detected.

In the animals treated only with DADS, the colonic sections looked like the controls. When DMH was injected along with DADS, the above observations were strongly attenuated and were not observed in animals that received DADS prior to DMH treatment. Altogether, suggest the protective properties of DADS, in vitro and in vivo. This still needs further work to reveal the molecular mechanisms of DADS with anti-cancerous properties.

\section{Conclusion}

DADS (a major organosulfur compound in garlic oil) anti-cancer properties were studied in vitro and in vivo, RT-PCR and western blot data showed that DADS differentially modulates the gene expression in HT29 colon cancer cells. It represses the oncogenes and induces the tumour suppressor genes. DADS also attenuates and protects against the carcinogenic impact of DMH in the animal model. We suggest that DADS has a beneficial impact that may be due to its ability to induce histone acetylation and initiate apoptosis in cancer cells.

\section{References}

1. http://www.scirp.org/journal/PaperInformation.aspx?PaperlD=17219http:// www.nci.cu.edu.eg/lectures/NCl\%20registry\%202002-03.pdf.\%20

2. Sampieri CL, León-Córdoba K, Remes-Troche JM (2013) Matrix metalloproteinases and their tissue inhibitors in gastric cancer as molecular markers. J Cancer Res Ther 9: 356-363.

3. Kruk J (2014) Association between vegetable, fruit and carbohydrate intake and breast cancer risk in relation to physical activity. Asian Pac J Cancer Prev 15: $4429-4436$ 
4. Gupta B, Johnson NW (2014) Emerging and established global life-style risk factors for cancer of the upper aero-digestive tract. Asian Pac J Cancer Prev 15: 5983-5991.

5. López-Aparicio S, Hak C (2013) Evaluation of the use of bioethanol fuelled buses based on ambient air pollution screening and on-road measurements. Sci Total Environ 452-453: 40-9.

6. Wang XT, Miao Y, Zhang Y, Li YC, Wu MH, et al. (2013) Polycyclic aromatic hydrocarbons (PAHs) in urban soils of the megacity Shanghai: Occurrence source apportionment and potential human health risk. Sci Total Environ 447 80-89.

7. Oller-Arlandis V, Sanz-Valero J (2012) Cancer in the population under 19 years of age caused by chemical contamination in drinking water: A systematic review. Rev Panam Salud Publica 32: 435-443.

8. Tayyem RF, Bawadi HA, Shehadah IN, Abu-Mweis SS, Agraib LM, et al. (2015) Macro- and micronutrients consumption and the risk for colorectal cancer among Jordanians. Nutrients 7: 1769-1786.

9. Doll R, Peto R (1981) The causes of cancer: Quantitative estimates of avoidable risks of cancer in the United States today. J Natl Cancer Inst 66: 1191-1308.

10. Abdulla M, Gruber P (2000) Role of diet modification in cancer prevention Biofactors 12: 45-51

11. Sabaté J, Ang Y (2009) Nuts and health outcomes: New epidemiologic evidence. Am J Clin Nutr 89: 1643S-1648S.

12. Fini L, Piazzi G, Daoud Y, Selgrad M, Maegawa S, et al. (2011) Chemoprevention of intestinal polyps in ApcMin/+ mice fed with western or balanced diets by drinking annurca apple polyphenol extract. Cancer Prev Res (Phila) 4: 907-915.

13. Armstrong CM, Allred KF, Allred CD (2011) Dietary fish oil reduces DNA adduct formation while estradiol upregulates apoptosis in response to DNA damage in the rat colon. Dig Dis Sci 56: 2585-2594.

14. Komiyama Y, Mitsuyama K, Masuda J, Yamasaki H, Takedatsu H, et al. (2011) Prebiotic treatment in experimental colitis reduces the risk of colitic cancer. $J$ Gastroenterol Hepatol 26: 1298-1308.

15. Bordia A, Verma SK, Srivastava KC (1998) Effect of garlic (Allium sativum) on blood lipids, blood sugar, fibrinogen and fibrinolytic activity in patients with coronary artery disease. Prostaglandins Leukot Essent Fatty Acids 58: 257263.

16. Lund T, Stokke T, Olsen $\varnothing \mathrm{E}$, Fodstad $\varnothing(2005)$ Garlic arrests MDA-MB-435 cancer cells in mitosis, phosphorylates the proapoptotic BH3-only protein BimEL and induces apoptosis. Br J Cancer 92: 1773-1781.

17. Yi L, Ji XX, Tan H, Lin M, Tang Y, et al. (2010) Role of Ras-related C3 botulinum toxin substrate 2 (Rac2), NADPH oxidase and reactive oxygen species in diallyl disulphide-induced apoptosis of human leukaemia HL-60 cells. Clin Exp Pharmacol Physiol 37: 1147-1153.

18. Aquilano K, Vigilanza P, Filomeni G, Rotilio G, Ciriolo MR (2010) Tau dephosphorylation and microfilaments disruption are upstream events of the anti-proliferative effects of DADS in SH-SY5Y cells. J Cell Mol Med 14: 564577

19. Shin DY, Kim GY, Kim JI, Yoon MK, Kwon TK (2011) Anti-invasive activity of diallyl disulfide through tightening of tight junctions and inhibition of matrix metalloproteinase activities in $\mathrm{LNCaP}$ prostate cancer cells. Toxicol In Vitro 24 1569-1576.

20. Zhu Q, Jin Z, Wu W, Gao R, Guo B, et al. (2014) Analysis of the intestinal lumen microbiota in an animal model of colorectal cancer. PLoS One 9: e90849.

21. Cohen J, Wakefield CE, Tapsell LC, Walton K, Fleming CA, et al. (2015) Exploring the views of parents regarding dietary habits of their young cancersurviving children. Support Care Cancer 23: 463-471.

22. Tang M, Zhao M, Zhou S, Chen K, Zhang C, et al. (2014) Assessing the underlying breast cancer risk of Chinese females contributed by dietary intake of residual DDT from agricultural soils. Environ Int 73: 208-215.

23. Choi WJ, Kim J (2014) Dietary factors and the risk of thyroid cancer: A review. Clin Nutr Res 3: 75-88.

24. von Kleist S, Chany E, Burtin P, King M, Fogh J (1975) Immunohistology of the antigenic pattern of a continuous cell line from a human colon tumor. J Nat Cancer Inst 55: 555-560.

25. Gelsomino G, Corsetto PA, Campia I, Montorfano G, Kopecka J, et al. (2013) Omega 3 fatty acids chemosensitize multidrug resistant colon cancer cells by down-regulating cholesterol synthesis and altering detergent resistant membranes composition. Mol Cancer 12: 137

26. Khare V, Lang M, Dammann K, Campregher C, Lyakhovich A, et al. (2014) Modulation of N-glycosylation by mesalamine facilitates membranous E-cadherin expression in colon epithelial cells. Biochem Pharmacol 87: 312 320.

27. Attoub S, Sperandio O, Raza H, Arafat K, Al-Salam S, et al. (2013) Thymoquinone as an anticancer agent: evidence from inhibition of cancer cells viability and invasion in vitro and tumor growth in vivo. Fundam Clin Pharmaco 27: 557-569.

28. Faux MC, Coates JL, Kershaw NJ, Layton MJ, Burgess AW (2010) Independen interactions of phosphorylated $\hat{I}^{2}$-catenin with E-cadherin at cell-cell contacts and APC at cell protrusions. PLoS One 5: e14127.

29. Liu B, Zhou Z, Zhou W, Liu J, Zhang Q, et al. (2014) Resveratrol inhibits proliferation in human colorectal carcinoma cells by inducing G1/Sâ€'phase cell cycle arrest and apoptosis through caspase/cyclinâ€'CDK pathways. Mol Med Rep 10: 1697-1702.

30. Sewify EM, Afifi OA, Mosad E, Zaki AH, E Gammal SA (2014) Cyclin D1 amplification in multiple myeloma is associated with multidrug resistance expression. Clin Lymphoma Myeloma Leuk 14: 215-222.

31. Xiao ZM, Wang XY, Wang AM (2015) Periostin induces chemoresistance in colon cancer cells through activation of the PI3K/Akt/survivin pathway. Biotechnol Appl Biochem 62: 401-406.

32. Zhang X, Ge YL, Tian RH (2009) The knockdown of c-myc expression by RNAi inhibits cell proliferation in human colon cancer HT-29 cells in vitro and in vivo. Cell Mol Biol Lett 14: 305-318.

33. Wu J, Akkuratov EE, Bai Y, Gaskill CM, Askari A, et al. (2013) Cell signaling associated with $\mathrm{Na}(+) / \mathrm{K}(+)$-ATPase: activation of phosphatidylinositide 3-kinase IA/Akt by ouabain is independent of Src. Biochemistry 52: 9059-9067.

34. Khatua TN, Adela R, Banerjee SK (2013) Garlic and cardioprotection: Insights into the molecular mechanisms. Can J Physiol Pharmacol 91: 448-458.

35. Mansoor TA, Borralho PM, Luo X, Mulhovo S, Rodrigues CM, et al. (2014) 6-Acetonyldihydrochelerythrine Is a Potent Inducer of Apoptosis in HCT116 and SW620 Colon Cancer Cells. J Nat Prod 77: 1825-1830.

36. Lee JY, Jee SB, Park WY, Choi YJ, Kim B, et al. (2014) Tumor suppresso protein p53 promotes 2-methoxyestradiol-induced activation of Bak and Bax leading to mitochondria-dependent apoptosis in human colon cancer HCT116 cells. J Microbiol Biotechnol 28; 24: 1654-1663.

37. van Miltenburg $\mathrm{MH}$, van Nimwegen MJ, Tijdens I, Lalai $\mathrm{R}$, Kuiper $\mathrm{R}$, et al. (2014) Mammary gland-specific ablation of focal adhesion kinase reduces the incidence of p53-mediated mammary tumour formation. Br J Cancer 110: 2747 2755.

38. Sui X, Kong N, Wang X, Fang Y, Hu X, et al. (2014) JNK confers 5-fluorouracil resistance in p53-deficient and mutant p53-expressing colon cancer cells by inducing survival autophagy. Sci Rep 4: 4694.

39. Agarwal MK, Agarwal ML, Athar M, Gupta S (2004) Tocotrienol-rich fraction of palm oil activates $\mathrm{p} 53$, modulates $\mathrm{Bax} / \mathrm{Bcl} 2$ ratio and induces apoptosis independent of cell cycle association. Cell Cycle 3: 205-211.

40. Yi L, Ji XX, Tan H, Lin M, Tang Y, et al. (2010) Role of Ras-related C3 botulinum toxin substrate 2 (Rac2), NADPH oxidase and reactive oxygen species in diallyl disulphide-induced apoptosis of human leukaemia HL-60 cells. Clin Exp Pharmacol Physiol 37: 1147-1153.

41. Tutar Y (2015) Inhibition of Heat Shock Protein 70 and 90 (Hsp70 And Hsp90) in Target Spesific Cancer Treatment. Adv Tech Biol Med 3: 2.

42. Jego G, Hazoumé A, Seigneuric R, Garrido C (2013) Targeting heat shock proteins in cancer. Cancer Lett 332: 275-285.

43. Zhang S, Huang WB, Wu L, Wang LY, Ye LB, et al. (2014) A novel suberoylanilide hydroxamic acid histone deacetylase inhibitor derivative, N25, exhibiting improved antitumor activity in both human U251 and H460 cells. Asian Pac J Cancer Prev 15: 4331-4338.

44. Altonsy MO, Habib TN, Andrews SC (2012) Diallyl disulfide-induced apoptosis in a breast-cancer cell line (MCF-7) may be caused by inhibition of histone deacetylation. Nutr Cancer 64: 1251-1260.

45. Sivagami G, Vinothkumar R, Bernini R, Preethy CP, Riyasdeen A, et al. (2012) Role of hesperetin (a natural flavonoid) and its analogue on apoptosis in HT29 human colon adenocarcinoma cell line--a comparative study. Food Chem Toxicol 50: 660-671. 
Citation: Altonsy MO, Habib TN, Hassanain EISA, Mokhtar GS (2015) Diallyl Disulphide Protects against Colon Cancer in vitro, of HT-29 Cells and in Male Rabbits of Colon Cancer Model: An Analysis of Genetic and Epigenetic Variations. Mol Biol 4: 136. doi:10.4172/2168-9547.1000136

Page 7 of 7

46. Altonsy MO, Andrews SC, Tuohy KM (2010) Differential induction of apoptosis in human colonic carcinoma cells (Caco-2) by Atopobium, and commensal, probiotic and enteropathogenic bacteria: mediation by the mitochondrial pathway. Int J Food Microbiol 137: 190-203.
47. Karczmarski J, Rubel T, Paziewska A, Mikula M, Bujko M, et al. (2014) Histone H3 lysine 27 acetylation is altered in colon cancer. Clin Proteomics 11: 24. 